\title{
Transactions Of Agricultural Land Revenue By Act No. 2 Of 1960 On Sharing Agreement In District Anjatan Of Indramayu
}

\author{
Mentari Dessy Wijayanti ${ }^{1}$ and Akhmad Khisni ${ }^{2}$
}

Abstract. The purpose of this study was to know and understand execution of transactions for the results of agricultural land pursuant to Act No. 2 of 1960 on Revenue Sharing Agreement in the district Anjatan of Indramayu and to know, understand, and analyze constraints and solutions in transactions for the results of agricultural land pursuant to Act No. 2 of 1960 on Revenue Sharing Agreement in the district Anjatan of Indramayu.

Based on the analysis concluded that the implementation of the agreement for the results of agricultural land in the district Anjatan of Indramayu has not entirely based on the provisions of Act No. 2 of 1960 on revenue-sharing agreements, since in fact the local community in terms of the implementation of revenue-sharing agreements mainly staple crops still based on the provisions of customary law and local practice, it can be seen from the shape of the agreement, the term of the agreement and the division of land results in the implementation of agricultural land revenue sharing agreements. Factors that hinder the implementation of revenue-sharing agreements on agricultural land in the district Anjatan of Indramayu according to Act No. 2 of 1960 on revenue sharing agreements often expressed by farmers when the implementation of revenue-sharing agreements follow the rules of the Act is the problem of a complicated process and timeframes long for the manufacture of revenue-sharing agreements. Keywords: Transaction; Agreement; Sharing.

\section{Introduction}

Land has a very important meaning for the existence of individuals in the community for survival that have economic value as a source of human life support in the future. The importance of soil for human survival, because there people live, grow, and thrive, even as well as a burial place at the time of his death. ${ }^{3}$

The public need to be ground from day to day continues to increase, in line with the speed of development in all areas of life carried out by the Indonesian nation. Thus, the function of the land is progressing tailored to the needs of diverse human, while the amount of land available is relatively limited, so that there is an imbalance between land supplies with demand for land which can lead to problems.

The arrangement of the control of land ownership has been recognized and implemented since centuries by the countries in the world to make reforms or reform the structure of agrarian particularly land done to improve the welfare of the people especially the people of the farmer who originally did not have arable land / plots to landless with pattern agrarian reform or known as the (reform). ${ }^{4}$

\footnotetext{
1 Students Master of Notary, Sultan Agung Islamic University Semarang email mentari.ind2212@gmail.com

${ }^{2}$ Faculty of Law Universitas Islam Sultan Agung

${ }^{3}$ Surojo Wignjodipuro, 1982, Pengantar dan Asas-asas Hukum Adat, Gunung Agung, Jakarta, p. 197.

${ }^{4}$ Literally the term comes from the English reform consisting of the word "land" means land and the word "reform" which means an overhaul. Therefore, land reform can be interpreted simply as an overhaul of the land. However, the concept of land reform really is not as simple as that, which means that not only revamp or overhaul land ownership structure, but an overhaul of the human relationship with the land, the relationship between humans with respect to the ground,
} 
For that, the government as policy maker to make a rule that set on the ground aimed at prosperity of the people, especially for prosperity of farmers. Policies on land set in the Act No. 5 of 1960 on Basic Regulation of Agrarian (BAL). Seen from the content and purpose of the Basic Agrarian Law is a form of certainty law to the public about the rights over land, especially peasantry.

The limited agricultural land pushed many farmers with land narrow and farm workers (landless agricultural) work on the ground Another sharing system for livelihood, for it is still necessary or opened the possibility of the use of agricultural land by people who do not own land, for example by way of lease, profit sharing, lien and others.

Agreement with the cultivation of agricultural land results have been executed since the first even been passed down from generation to generation. The revenue share agreement made by landowners who do not have time or are not able to work on the land and then work together in the form of profit sharing with farmers who have land or land which has no principal livelihood is work the land for agriculture.

Sharing agreement is an agreement by whatever name called, held between the owners on the one hand and a person or legal entity on the other hand, which in this Act referred to as "tenants", pursuant to which the tiller allowed by that owner to conduct agricultural activities on top land owner, with the distribution of the results between the two sides. ${ }^{5}$

In Indonesia, Law approved profit sharing agreement and enacted on January 7, 1960, published in the State Gazette of 1960 No. 2, with the explanation memory in State Gazette. ${ }^{6}$ With the Act No. 2 of 1960 on Revenue Sharing Agreement, the implementation of land revenue sharing agreements between the parties should be based on a fair distribution. In addition, the rights and obligations of both parties are also listed in the Act. Especially with regard to ensuring the proper legal standing for the tenants, such things do not just affect the increase in production but also affect the fulfillment of people's need for food and clothing.

In the practice of Act No. 2 of 1960 on Revenue Sharing Agreement is not fully implemented by the parties to the agreement for the produce, but the parties are using custom or customary law in its implementation. As an example of an agreement which should in Act No. 2 of 1960 on Revenue Sharing Agreement is made in written form in the presence of the village chief, it is inversely proportional to the practice because in general the agreement is implemented in the form of unwritten and agreement between the two sides only.

One of the government's policy of equipment that has been molded to achieve the objectives of equity above 2 lines is Act No. 2 of 1960. Although the Act No. 2 of 1960 had been enacted in 1960, but until today in practice sharing system was performed according to customary law. ${ }^{7}$ Legally Act concerning for this result is still valid and has not been revoked by the government, but based on the above quote that Act No. 2 of the Production Sharing Agreement are not effective in the community.

The parties prefer to use customary law in the implementation of revenue-sharing agreements. In district Anjatan of Indramayu sharing agreement is an agreement based on the habits that have been around a long time, which is derived from their ancestors.

in order to increase farmers' incomes and it is fundamental overhaul. seehttp: // tifiacerdikia. wordpress.com/lecture/lecture-2/, Access on April 12, 2014, at 06: 28 pm.

${ }^{5}$ Article 1 Act No. 2 of 1960 on Revenue Sharing Agreement.

6 Soedjarwo Soeromiharjo, (ed.), 2008, Pengabdian Seorang Guru Pejuang Petani Bunga Rampai : Fokus pada Mengangkat Harkat Petani, Gajah Hidup, Jakarta, p. 87.

7 Hesti Rukmiati Widjaya, "Undang-undang pokok perjanjian bagi hasil sebagai sarana pembangunan pertanian di Indonesia", Pidato Dies Natalis, Senat Terbuka Universitas Brawijaya 7 Pebruari 1981, p. 6. 
The agreement is based on mutual trust kinship between the parties. So that people in the district Anjatan of Indramayu rarely entered into an agreement for the results of the agricultural land in front of village officials, let alone ratify the agreement before the local district.

This is clearly not in accordance with the provisions of Act No. 2 of 1969 on revenuesharing agreements. In addition, other problems arise, namely about inequality or injustice for any of the parties in terms of revenue (income) obtained and the sharing of expenses for the agreement took place between tenants and landowners are largely detrimental to the tenants. Thus, based on these provisions, the implementation of revenue-sharing agreements no longer appropriate.

The above shows that the production sharing agreement requires a new regulations that can be accepted by the community to the agreement for the crops of the plant does not harm either party, even though the parties prefer to use customary law and led to Law for the results are not effective in practice.

\section{Research methods}

The method used is normative, with specification of the study is a descriptive analysis through the stages of the research literature and field research with engineering submitting data through literature studies and interviews, then analyzed the data using the method of analysis of normative qualitative without using mathematical formulas and figures.

\section{Results and Discussion}

\subsection{Implementation of the Agricultural Land Transactions Sharing Based on Act No. 2 of 1960 on Revenue Sharing Agreement in the district Anjatan of Indramayu}

Sharing agreement on the agricultural land in the district Anjatan crops during this based on trust and agreement between the tenant farmers with land owners, so as to the validity of a production sharing agreement between the owners and tenants of land only by agreement of both parties. The agreement only orally by consensus and mutual trust between the two sides. This is as trust asset for a permit tenants to be able to manage a farm that is not hers.

The basis of the production sharing agreement made by the land owners and tenants is a sense of family, a sense of mutual trust between them and revenue sharing agreements are made solely by word of mouth and trust each other, and the prevailing tradition from generation to generation. To get a clear picture of the shape of revenue-sharing agreements that occurred in district Anjatan below table are presented on the form of profit sharing agreements, namely:

Table 1.

Forms of Revenue Sharing Agreement

\begin{tabular}{|c|c|c|c|}
\hline No. & Form of Agreement & Frequency & $\%$ \\
\hline 1. & Written & 0 & 0 \\
\hline 2. & Unwritten & 18 & 100 \\
\hline & Total & 18 & 100 \\
\hline
\end{tabular}

Sources: Primary data is processed, 2016

According to the table above, it can be concluded that the sharing agreement on crops 
between owners and tenants in district Anjatan done verbally / unwritten, that is as much as $100 \%$, while an agreement in writing between the parties in accordance with that specified in the Act of No. 2 of 1960 on Revenue Sharing Agreement did not exist.

In addition, the revenue-sharing agreements must be made before the village chief where the land is located. When connected with the practice occurred in the district Anjatan, it can be said that the entire agreement for the results made it generally only done by both parties without the presence of a third party. However, the parties have become accustomed and feel no worry in making arrangements for the results even though it does not involve village officials to make, as long as the parties to implement the agreement for these results have never had a dispute or a problem related to the revenue-sharing agreements they have made,

It is encouraging the farming community of crops in the district Anjatan prefer to use the hereditary habits in implementing the agreement for the result rather than the manner specified in Act No. 2 of 1960 on revenue-sharing agreements, which specify that the revenue-sharing agreements must be made in the presence of the Head Village.

Based on the results of research conducted by the authors also found several reasons why farmers in district Anjatan tend to use the provisions of the customs rather than implement the provisions of Act No. 2 of 1960, which is a matter of the process of making arrangements for the results according to Act No. 2 of 1960 the process is much longer and costs more, for farmers who lay of the land or the house is far from the village chief's office or the District office. For other farmers in the district Anjatan not familiar with the provisions of Act No. 2 of 1960 on revenue-sharing agreements.

Then the procedures of agricultural land production sharing agreement at the next annual crops is that the agreement for the crops of the crops are made to be announced in the density of the village by the village chief. It is intended that the revenue sharing agreements become clear and that everyone knows of the existence of the related agreement. In district Anjatan, agricultural land revenue sharing agreements on crops that were made between the landlord and serf, almost the whole there is nothing published in the density of the village.

Based on the above it can be concluded that the farmers do more revenue sharing agreements based on the provisions of the local customary law rather than referring to Act No. 2 of 1960, because:

- Lack of knowledge of farming communities on Act No. 2 of 1960 on Revenue Sharing Agreement itself.

- The procedure of making revenue-sharing agreements in Act No. 2 of 1960 on Revenue Sharing Agreement is very complicated, which must be made before the village chief, to be approved by the sub-district and village should be announced in the meeting.

- The procedures performed in a production sharing agreement in customary law easier.

- Sharing agreements that do it is already a tradition handed down.

- Sharing agreement that customary law carried out rare dispute.

In Article 4 paragraph (1) of Act No. 2 of 1960 on Production Sharing Contract has been determined regarding the period for sharing agreement, which is for the fields time period of at least three years and for the duration of dry land for at least five years. It is intended that tenants receive the guarantee to work a claim within a reasonable time. 
Table 2.

Term Revenue Sharing Agreement

\begin{tabular}{lccc}
\hline No. & Duration of the agreement & Frequency & $\%$ \\
\hline 1. & During One Year Harvest & 12 & 67 \\
\hline 2. & Not Forwarded & 6 & 33 \\
\hline & Total & 18 & 100 \\
\hline
\end{tabular}

Sources: Primary data is processed, 2016

Based on the above table it can be concluded that the agreement for the results that occurred in district Anjatan a lot to do with the validity period of one year of the harvest, that of 18 respondents (100\%), 12 respondents (67\%) expressed agreement is valid for a period of one harvest, while the rest, ie 6 respondents (33\%) of respondents valid period of uncertainty between the owners and tenants.

Regarding the term of the agreement for the crops of the staple crops in district Anjatan in practice, almost all the deal carried out is not specified duration. If determined also on very short terms is only held within one year of harvest. In general, a period of ongoing sharing agreement between the landlord and tenants are fully dependent on the will of the landowner.

In the execution of which occurred in the district Anjatan regarding the term of the agreement to result in annual crops harvested only valid for one year, from planting to harvest. Term of the agreement for the results of crops, that the landowners have the time or the opportunity to work on the land, the crops after the harvest, farmers are obliged to submit cultivated land owner. Then landowners work or cultivate the land by planting crops other than crops without termination for results. By the way at harvest have been implemented and the harvest has been divided, so when it automatically crops production sharing agreement is broken for one year the season has finished or in other words the second crop season has ended.

Agreement for agricultural products on crops is done by farmers in the district Anjatan based on the provisions of customary law and local customs. Therefore, all the impact will be governed by the provisions of customary law and local customs.

According to the author interview with Mr. Tohari stated that due to non-performance if the content of the production sharing agreement by tenants in accordance with the agreements that have been made, then severed ties sharing agreement after the harvest season crops. From the interview, it can be concluded that if the event occurs cultivators did not fulfill its obligations to the owner, it rarely happens termination sharing agreement at the time, but it was decided at the time of the harvest has been completed.

Whatever the reason, if tenants can not be accepted by the owner of the land because it is considered outrageous and usually after the termination event occurs then for the next tenants are no longer trusted by the local community. When viewed losses suffered by the serf to result in crops that the land owners to charge the implementation of the planting to the tiller as an example of the cost burden to manage the land but the land owners can summary or arbitrary finish sharing agreement that land before the period discharged, giving rise to the dispute.

In this regard, the Head of Anjatan Village stated that, if the tenants do not work on the farm was well and truly, so the results are unsatisfactory or failed crops, usually the owner of the land will take back the land from the tiller after the completion of the harvest and after harvest the agreement also ends, but otherwise if the tenants manage the land well and very good yields, then the owner will continue to defend the tenants to manage the 
land back.

In accordance with what has been described above, according to the customary law of land the size of part proceeds received by the owners and tenants depending on the terms agreed upon by both parties. In general, the position of tenant farmers are very weak when compared with the position of landowners, tenant farmers consequently not accept the terms proposed by the landowner, although with the requirements burdensome and detrimental to the tenants.

In Act No. 2 of 1960 on Revenue Sharing Agreement regulates land portion of the proceeds received by the owners and tenants as enshrined in Article 7 states as follows:

(1) The portion of the produce of the land that is rightfully tenants and owners for each area of the Autonomous ${ }^{8}$. Level II is set by the Regent / Head of the Autonomous Region Level II is concerned, taking into account soil types, terrain, population density, charity set aside before the split, and economic factors as well as the provisions of the local custom.

(2) Autonomous District Head of Level II notifies its decision concerning the establishment of sharing the land taken pursuant to paragraph 1 of this article to the Administration Daily and the Regional Representatives Council is concerned.

Based on the results of research conducted in Indramayu no legislation either a decree or other written rules relating to the sharing agreement concerning the implementation of revenue-sharing agreements and a counterweight to the results. Indramayu Government just issued a decree on matters relating to the assets of the area.

Act No. 2 of 1960 provides guidelines for a counterweight to the results of land between owners and tenants is to plant paddy rice in a ratio of $1: 1$ (one to one) and for the crops in the fields and crops on dry land, farmers get $2 / 3$ section while the owners get $1 / 3$. In practice, according to interviews with respondents stating that, division of the results done during the harvest period in accordance with the agreement that has been agreed upon, the land owners and tenants divide the crops in the agreement that has been made.

Habits local custom to plant crops on dry land species owner gets $1 / 3$, while tenants get $2 / 3$ of the crop. In the event of crop failure risks are shared, including the sharing of proceeds or losses are also borne jointly. The balance of the distribution of these results has become a habit for the local community, but in the study met other events, namely because the owner felt sorry for tilling the soil generally in the first growing season and the results of the land is divided according to the agreement, while the following season the land owners give entirely the result of land to the tiller. But in other villages encountered another incident that revenue sharing agreements that took place between the owners and tenants of land when the division of the balance of the harvest the entire crop is given to the owner of the land with the provisions of all charges ranging from seeds, fertilizer, the cost of cultivation and harvest borne by the owner of the land, This happens constituted by the tenants who want payback against the land owners.

Based on the above it can be concluded that the division yields determined by the tenants and owners in accordance with their wishes. No compensatory clear and definite as the balance that has been determined by the Law on Production Sharing Agreements, both for the rice crop or crops.

\subsection{Constraints and Solutions in Implementation Transaction Sharing Based Agricultural Land Act No. 2 of 1960 on Revenue Sharing Agreement in the district Anjatan of Indramayu}

\footnotetext{
${ }^{8}$ Autonomous term equivalent to the district / city level, the term is no longer valid after the enactment of Local Government Act.
} 
In Indonesia, the Law legalized profit sharing agreement and enacted on January 7, 1960, published in the State Gazette of 1960 No. 2, with the explanation memory in State Gazette. ${ }^{9}$ With the Act No. 2 of 1960 on Revenue Sharing Agreement, the implementation of land revenue sharing agreements between the parties should be based on a fair distribution. In addition to the rights and obligations of both parties are also listed in the legislation.

Especially with regard to ensuring the legal position that is appropriate for the tenants, such things do not just affect the increase in production but also affect the fulfillment of people's need for food and clothing, but in practice the Act No. 2 of 1960 on Revenue Sharing Agreement is not fully implemented by the parties to the agreement for the produce, but the parties are using custom or customary law in its implementation.

Examples of agreements which should have been in Act No. 2 of 1960 on Revenue Sharing Agreement is made in written form in the presence of the village chief, it is inversely proportional to the practice because in general the agreement is implemented in the form of unwritten and agreement between the two sides only,

One of the government's policy of equipment that has been molded to achieve the target of 2 (two) lines above equalization is Basic Law Sharing (UUPBH). Although UUPBH was enacted in 1960, but until today in practice sharing system still performed according to customary law. ${ }^{10}$ Legally laws on for this result is still valid and has not been revoked by the government, but based on the above quote authors agree, that Act No. 2 of the Production Sharing Agreement are not effective in the community. The parties prefer to use Customary law in the implementation of revenue-sharing agreements.

In district Anjatan of Indramayu sharing agreement is an agreement based on the habits that have been around a long time, which is derived from their ancestors. The agreement is based on mutual trust kinship between the parties, so that the people in the district Anjatan rarely entered into an agreement for the crops of the crops in front of village officials, let alone ratify the agreement before the local district.

This is clearly not in accordance with the provisions of Act No. 2 of 1969 on the Revenue Sharing Agreement. In addition, other problems arise, namely about inequality or injustice for any of the parties in terms of revenue (income) obtained and the sharing of expenses for the agreement took place between tenants and landowners are largely detrimental to the tenants. Thus, based on these provisions, the implementation of revenue-sharing agreements no longer appropriate.

Above, indicate that the related agreement requires a new regulations that can be accepted by the community to the agreement for the crops of the crops is not detrimental to either party, even though the parties prefer to use customary law and lead to Act for those results to be effective in its implementation.

According to Article 3 of Act No. 2 of 1960 on Revenue Sharing Agreement specify that all agreements for the results to be made by the owners and tenants in writing in the presence of the village chief place lay of the land in question, in the presence of two witnesses, each of the owners and tenants. In addition, the agreement must be ratified by the sub-district and village should be announced in the meeting. Sharing agreement in the district Anjatan of Indramayu, generally carried out by customary law, the applicable provisions of unwritten law.

\footnotetext{
${ }^{9}$ Soedjarwo Soeromiharjo, et.al (ed.), Pengabdian Seorang Guru Pejuang Petani Bunga Rampai : Fokus pada Mengangkat Harkat Petani, Gajah Hidup, Jakarta, 2008, p. 87.

10 Hesti Rukmiati Widjaya, "Undang-undang Pokok Perjanjian Bagi Hasil sebagai Sarana Pembangunan Pertanian di Indonesia", Pidato Dies Natalis Pada Rapat Senat Terbuka, Universitas Brawijaya, Malang, 7 Februari 1981, p. 6.
} 
Here, the effectiveness of a law in society means that concerns about the workings of the law in regulating and forcing people to adhere to the law. Ineffectiveness of Act No. 2 of 1960 on revenue-sharing agreements in the district Robatal based on several elements. According to Lawrence Friedman, elements of the legal system consists of legal structures (legal structure), the substance of the law (legal substance), and the legal culture (legal culture). ${ }^{11}$

The first element of the legal system is a legal structure, namely its own law enforcement. When law enforcement about following the rules, then the people would obey the rules so that the law can be effective in the community. ${ }^{12}$ The legal structure may include the executive, legislative and judicative and related agencies, such as police, prosecutors and courts. According to the authors, according to Friedman's theory, law enforcement is very weak revenue sharing agreements because the performance of law enforcement officers are less able to work optimally.

The second element is the substance of the law, which is the core of the legislation itself. Any legislation should be made clearly and in detail, and it contains the terms of the legislation is good, that meet the elements of philosophical, juridical, and sociological. ${ }^{13}$ In this study related to the law on production sharing agreement, according to the author in accordance with the above Friedman's theory, the law for the legal substance of this result is weak and needs to be adjusted.

The third element is a legal culture that is how the attitude of the legal community in the law where it is run. If the awareness of society to meet the rules that have been applied, the community will be a contributing factor, but if people do not comply with the existing rules, the people will be the main limiting factor in the enforcement of the regulations in question. ${ }^{14}$ When linked with the production sharing agreement on staple crops in district Anjatan the farming community in general lay of legislation for the result, so that the farmers in implementation the district Anjatan still using the existing customary law handed down in the village.

In district Anjatan implementation of revenue-sharing agreements farmland there are factors that prevent the implementation of the production sharing agreement, which is not yet fully based on the provisions of Act No. 2 of 1960, in other words, the implementation is based on the provisions of customary law and local customs. This is evident from the various things that are described as follows:

- Form of Agreement

In Act No. 2 of 1960 on Revenue Sharing Agreement confirms that the agreements for the results to be made by the owners and tenants in writing before the village chief, the presence of two witnesses, each of the owners and tenants, then ratified by the Head of district and was published in the density region of the village. However, in the district Anjatan of Indramayu form the agreement is only based on an agreement between the two sides only, made verbally, not in front of the village chief, no approved sub-district, there are no announced the village, and not an absolute must-attend by witnesses.

- Duration of the agreement

In Act No. 2 of 1960 on Revenue Sharing Agreement are held for a certain period, namely for the fields of at least three years and for the soil to dry for at least five years. Practices that occurred in the district of Anjatan regarding the term of the agreement to

${ }^{11}$ Lawrence Friedman, American Law, W.W. Norton \& Company, London, 1984, p. 6.

12 Soerjono Soekanto dan Mustofa Abdullah, Sosiologi Hukum dalam Masyarakat, Rajawali, Jakarta, 1982, p. 13.

13 Ibid.

${ }^{14}$ Ibid. 
result in annual crops harvested only valid for one year, from planting to harvest. This does not only apply to wet soils but also on dry land in the district Anjatan.

- Sharing the Land

According to Act No. 2 of 1960 on Revenue Sharing Agreement, namely ground counterpoise results for paddy 1: 1 (ratio of one to one), while for crops like paddy dry fields including tobacco is $2 / 3$ to served and $1 / 3$ parts for landowners, whereas in actual counterweight to the results of the soil crops, both planted in wet or dry soil is the same, namely in accordance with the agreement or agreements made by the parties in advance.

Factors that hamper the implementation of revenue-sharing agreements in the district Anjatan according to Act No. 2 of 1960 on revenue share agreement because:

- Factors relatively low education of the farming community.

- At least the public's knowledge of farmers on Act No. 2 of 1960 on Revenue Sharing Agreement.

- The lack of information on the law of the competent authority of the Act No. 2 of 1960 on revenue-sharing agreements.

- The notion that the procedures of the farming community sharing agreement according to Act No. 2 of 1960 on Revenue Sharing Agreement is very convoluted.

See implementation that occurred in district Anjatan, that the revenue-sharing agreements in the district Anjatan yet fully under Act No. 2 of 1960 on Revenue Sharing Agreement, to enhance the legal awareness district of Anjatan, then the village should actively conduct legal counseling on any regulations. Devices in the district Anjatan of Indramayu, should coordinate or cooperate with the district and contact an agency the ultimate authority for this problem. As the Office of Agriculture which hold information on the law relating to the issue of agricultural land. It can also be done on other issues.

So that Act No. 2 of 1960 on Revenue Sharing Agreement can be implemented properly, then for any violations that occur in the implementation of the agreement for agricultural products subject to strict sanctions in accordance with the existing regulations, in order to ensure legal certainty for the owners and tenants of land so no one injured party or advantageous.

\section{Closing}

\subsection{Conclusion}

- Implementation of the agreement for the results of agricultural land in the district Anjatan of Indramayu has not entirely based on the provisions of Act No. 2 of 1960 on revenue-sharing agreements, since in fact the local community in terms of the implementation of revenue-sharing agreements, especially crops are still based on the provisions of customary law and local customs, it can be seen from the shape of the agreement, the term of the agreement and the division of land results in the implementation of agricultural land revenue sharing agreements.

- Factors that hinder the implementation of revenue-sharing agreements on agricultural land in the district Anjatan of Indramayu according to Act No. 2 of 1960 on revenue sharing agreements often expressed by farmers when the implementation of revenuesharing agreements follow the rules of the Act is the problem of a complicated process and timeframes long for the manufacture of revenue-sharing agreements. In addition, the absence of data on farmers involved in agricultural land revenue sharing agreements. so there is no accurate data on the number of farmers who implement the revenue-sharing agreements in the district Anjatan. 


\subsection{Suggestion}

- Need holding counseling related to issues of agricultural land, especially regarding sharing agreements, in addition to the offenses in the implementation of the agreement for agricultural products subject to strict sanctions in accordance with the existing regulations, in order to ensure legal certainty for the owners and tenants of land so that no one the injured party or advantageous.

- The village must be proactive in seeking out or get information about things that are new, then they should immediately inform the villagers to sharing the land between owners and tenants on the basis of fair and to ensure also the legal position that is appropriate for the tenants that, by asserting the rights and obligations of both tenants and owners.

\section{Bibliography}

[1] Surojo Wignjodipuro, 1982, Pengantar dan Asas-asas Hukum Adat, Gunung Agung, Jakarta

[2] seehttp: // tifiacerdikia. wordpress.com/lecture/lecture-2/, Access on April 12, 2014, at 06: $28 \mathrm{pm}$.

[3] Soedjarwo Soeromiharjo, (ed.), 2008, Pengabdian Seorang Guru Pejuang Petani Bunga Rampai : Fokus pada Mengangkat Harkat Petani, Gajah Hidup, Jakarta.

[4] Hesti Rukmiati Widjaya, "Undang-undang pokok perjanjian bagi hasil sebagai sarana pembangunan pertanian di Indonesia", Pidato Dies Natalis, Senat Terbuka Universitas Brawijaya 7 Pebruari 1981.

[5] Soedjarwo Soeromiharjo, et.al (ed.), Pengabdian Seorang Guru Pejuang Petani Bunga Rampai : Fokus pada Mengangkat Harkat Petani, Gajah Hidup, Jakarta, 2008.

[6] Hesti Rukmiati Widjaya, "Undang-undang Pokok Perjanjian Bagi Hasil sebagai Sarana Pembangunan Pertanian di Indonesia", Pidato Dies Natalis Pada Rapat Senat Terbuka, Universitas Brawijaya, Malang, 7 Februari 1981

[7] Lawrence Friedman, American Law, W.W. Norton \& Company, London, 1984.

[8] Soerjono Soekanto dan Mustofa Abdullah, Sosiologi Hukum dalam Masyarakat, Rajawali, Jakarta, 1982. 